\title{
Arsenic-Redox Transformation and Plant Growth Promotion by Purple Nonsulfur Bacteria Rhodopseudomonas palustris CS2 and Rhodopseudomonas faecalis SS5
}

\author{
Kanza Batool, Fatima tuz Zahra, and Yasir Rehman \\ Department of Microbiology \& Molecular Genetics, University of the Punjab, Lahore, Pakistan \\ Correspondence should be addressed to Yasir Rehman; yasir.mmg@pu.edu.pk
}

Received 5 November 2016; Revised 9 January 2017; Accepted 19 January 2017; Published 12 March 2017

Academic Editor: Wen-Jun Li

Copyright (C) 2017 Kanza Batool et al. This is an open access article distributed under the Creative Commons Attribution License, which permits unrestricted use, distribution, and reproduction in any medium, provided the original work is properly cited.

Arsenic (As) is a well-known toxic metalloid found naturally and released by different industries, especially in developing countries. Purple nonsulfur bacteria (PNSB) are known for wastewater treatment and plant growth promoting abilities. As-resistant PNSB were isolated from a fish pond. Based on As-resistance and plant growth promoting attributes, 2 isolates CS2 and SS5 were selected and identified as Rhodopseudomonas palustris and Rhodopseudomonas faecalis, respectively, through 16S rRNA gene sequencing. Maximum As(V) resistance shown by $R$. faecalis SS5 and $R$. palustris CS2 was up to 150 and $100 \mathrm{mM}$, respectively. $R$. palustris CS2 showed highest As $(\mathrm{V})$ reduction up to $62.9 \%$ (6.29 $\pm 0.24 \mathrm{mM}$ ), while $R$. faecalis SS5 showed maximum As(III) oxidation up to $96 \%$ $(4.8 \pm 0.32 \mathrm{mM})$, respectively. Highest auxin production was observed by $R$. palustris CS2 and $R$. faecalis SS, up to $77.18 \pm 3.7$ and $76.67 \pm 2.8 \mu \mathrm{g} \mathrm{mL}{ }^{-1}$, respectively. Effects of these PNSB were tested on the growth of Vigna mungo plants. A statistically significant increase in growth was observed in plants inoculated with isolates compared to uninoculated plants, both in presence and in absence of As. R. palustris CS2 treated plants showed $17 \%(28.1 \pm 0.87 \mathrm{~cm})$ increase in shoot length and $21.7 \%(7.07 \pm 0.42 \mathrm{~cm})$ increase in root length, whereas $R$. faecalis SS5 treated plants showed $12.8 \%(27.09 \pm 0.81 \mathrm{~cm})$ increase in shoot length and $18.8 \%(6.9 \pm 0.34 \mathrm{~cm})$ increase in root length as compared to the control plants. In presence of As, $R$. palustris CS2 increased shoot length up to $26.3 \%$ $(21.0 \pm 1.1 \mathrm{~cm})$, while root length increased up to $31.3 \%(5.3 \pm 0.4 \mathrm{~cm})$, whereas $R$. faecalis SS5 inoculated plants showed $25 \%(20.7 \pm$ $1.4 \mathrm{~cm})$ increase in shoot length and $33.3 \%(5.4 \pm 0.65 \mathrm{~cm})$ increase in root length as compared to the control plants. Bacteria with such diverse abilities could be ideal for plant growth promotion in As-contaminated sites.

\section{Introduction}

Arsenic (As) is a ubiquitous toxic metalloid which is also released from several industrial processes such as mining, tanning of hides, and combustion of coal. Due to these reasons, the level of As in drinking waters of many areas has been increased beyond WHO standard drinking water limits $\left(0.01 \mathrm{mg} \mathrm{L}^{-1}\right)$ [1]. As is primarily found in two major forms: arsenate $[\mathrm{As}(\mathrm{V})]$ and arsenite [As(III)] [2]. As(III) is reported to be $\sim 100$ times more toxic as compared to $\mathrm{As}(\mathrm{V})[3,4]$. As $(\mathrm{V})$ causes harm to the cells by being analogous to phosphorous, replacing the latter in many chemical reactions [5]. As(III), on the other hand, affects activity of many enzymes by reacting with their sulfhydryl groups [6]. As is toxic to all life forms, including plants, animals, and human beings. Long-term exposure to As, especially through drinking water, can cause arsenicosis which is manifested as different types of cancers and skin allergies. In plants, the toxicity of As causes reduced growth and low yields [7]. As is toxic to microorganisms as well; however, several bacteria are known to resist and detoxify As. As-resistant bacteria are known to have effects on As-oxidation/reduction, methylation, and demethylation, as well as sorption and desorption as a result of their survival strategies against As-toxicity [8]. Such As-resistant bacteria are ideal for the bioremediation of As-contaminated lands. However, given the possible complexity and severity of the 
As-polluted sites, the bacteria should be metabolically diverse in order to thrive in different environments.

Purple nonsulfur bacteria (PNSB) are one of the most metabolically diverse and adaptable bacteria. They are phototrophic and are widely found in nature, especially in submerged habitats that are exposed to sunlight, such as rice paddies, sewage dumping sites, and riverbeds. These bacteria have an extensive range of growth modes and are capable of growing photoautotrophically/photoheterotrophically under anaerobic conditions in presence of incandescent light utilizing a variety of organic substrates and can also grow chemoorganotrophically under aerobic dark conditions [9]. These properties make them ideal for wastewater bioremediation [10]. Several strains of PNSB are also known to have plant growth promoting abilities in terms of nitrogen fixation [11], phosphate solubilization, and production of phytohormones such as indole-3-acetic acid and 5-aminolevulinic (ALA) [12]. The most common genera are Rhodobacter and Rhodopseudomonas, detected in $73 \%$ and $80 \%$ of the samples, respectively [13]. Some PNSB have also been reported to resist and detoxify several toxic compounds such as As [14]. Consequently, PNSB can also play a substantial role in As-biogeochemistry and bioremediation.

Isolation and characterization of metabolically diverse PNSB having abilities not only to detoxify As but also to support plant growth could be very useful for bioremediation purposes. This could help in reclamation of As-polluted sites for agriculture purposes.

\section{Materials and Method}

2.1. Sampling. Sampling was done from the fish pond near the University of the Punjab, Quaid-e-Azam campus, Lahore, Pakistan $\left(31^{\circ} 29^{\prime} 55.4^{\prime \prime} \mathrm{N} 74^{\circ} 17^{\prime} 31.9^{\prime \prime} \mathrm{E}\right)$. Sampling location in the pond was so selected that it was shallow enough to allow penetration of sunlight and deep enough to have anoxic conditions, perfect for PNSB. Thus, 3-4 feet deep water and sediment samples were collected. Temperature and $\mathrm{pH}$ of the samples were recorded. As(V) and As(III) were purchased as $\mathrm{Na}_{2} \mathrm{HAsO}_{4} \cdot 7 \mathrm{H}_{2} \mathrm{O}$ and $\mathrm{NaAsO}_{2}$, respectively. All the experiments were performed in triplicate.

2.2. Enrichment and Isolation of PNSB. Media suggested by Biebl and Pfennig [15] with slight modifications was used. The media contained freshly prepared basal medium $(0.33 \mathrm{gm}$ $\mathrm{KH}_{2} \mathrm{PO}_{4}, 0.33 \mathrm{gm} \mathrm{MgSO}_{4} \cdot 7 \mathrm{H}_{2} \mathrm{O}, 0.33 \mathrm{gm} \mathrm{NaCl}, 0.05 \mathrm{gm}$ $\mathrm{CaCl}_{2} \cdot 2 \mathrm{H}_{2} \mathrm{O}, 0.5 \mathrm{gm} \mathrm{NH} \mathrm{NH}_{4} \mathrm{Cl} 1.0 \mathrm{gm}$ sodium succinate, and $0.02 \mathrm{gm}$ yeast extract $\left.\mathrm{L}^{-1}\right)$ to which $0.5 \mathrm{~mL} \mathrm{FeSO} \cdot 7 \mathrm{H}_{2} \mathrm{O}$ $(0.02 \%)$ and $1.0 \mathrm{~mL}$ trace salt solution $\left(10.0 \mathrm{mg} \mathrm{ZnSO}_{4} \cdot 7 \mathrm{H}_{2} \mathrm{O}\right.$, $3.0 \mathrm{mg} \mathrm{MnSO}_{4} \cdot 4 \mathrm{H}_{2} \mathrm{O}, 30.0 \mathrm{mg} \mathrm{H}_{3} \mathrm{BO}_{3}, 20.0 \mathrm{mg} \mathrm{CoCl} \cdot 6 \mathrm{H}_{2} \mathrm{O}$, $2.0 \mathrm{mg} \mathrm{NiCl} \cdot 6 \mathrm{H}_{2} \mathrm{O}, 3.0 \mathrm{mg} \mathrm{Na} \mathrm{MoO}_{4} \mathrm{~L}^{-1}$ ) were added and autoclaved. After autoclaving, while still warm, $450 \mathrm{~mL}$ of media was aseptically poured in autoclaved $500 \mathrm{~mL}$ Schott bottles. Media were allowed to cool and $50 \mathrm{~mL}$ of each sample (10\% inoculum, water plus sediment) was inoculated aseptically, leaving little headspace. Media were overlaid with mineral oil and incubated at $28^{\circ} \mathrm{C}$ in the presence of incandescent light. Once the enrichment, reddish maroon colored bloom, was achieved ( $~ 10$ days incubation), samples were drawn aseptically, serially diluted, and plated on Pfennig agar media plates. Media supplemented with different carbon sources (sodium acetate, sodium citrate, maleic acid, sodium succinate, and sodium lactate) were also used to conclude which carbon source is more suitable for the growth of PNSB. Plates were incubated at $28^{\circ} \mathrm{C}$ for $5-7$ days in anaerobic jars (Oxoid) containing anaerobic sachet (Merck) in incandescent light. After incubation, PNSB were purified by streak plate method and characterized. PNSB were then cultured on Pfennig agar media (succinate) containing $1.0 \mathrm{mM} \mathrm{As}(\mathrm{V})$. PNSB that were able to grow in presence of $A s(V)$ were selected for further studies.

2.3. Minimum Inhibitory Concentration (MIC) of $A s(V)$. Pfennig media containing $50 \mathrm{mM}, 100 \mathrm{mM}$, or $150 \mathrm{mM}$ As(V) were prepared and dispensed in screw capped tubes followed by autoclaving. The media were inoculated with overnight cultures, overlaid with mineral oil, and incubated at $28^{\circ} \mathrm{C}$ in incandescent light for 6-7 days. Presence or absence of growth was recorded.

\subsection{As-Oxidation/Reduction Assay}

2.4.1. Qualitative Assay. Mineral medium [16], supplemented with $10 \mathrm{mM} \mathrm{As}(\mathrm{V})$ or $5 \mathrm{mM}$ As(III), was inoculated with PNSB and incubated at $37^{\circ} \mathrm{C}$ for 48 hours. After incubation, $200 \mu \mathrm{L}$ of each supernatant was taken in microtiter plate wells and mixed with $0.01 \mathrm{M} 12 \mu \mathrm{L} \mathrm{KMNO}_{4}$. Color development was observed and recorded. A change from purple to yellowish brown color indicates As(V) reduction to As(III) [17].

2.4.2. Quantitative Assay. Overnight PNSB cultures were harvested and pellets were washed (twice) with and resuspended in normal saline. Cell suspensions were divided into two sets of tubes: one set was supplemented with $10.0 \mathrm{mM}$ $\mathrm{As}(\mathrm{V})$ and the other set was supplemented with $5.0 \mathrm{mM}$ As(III) followed by incubation at $37^{\circ} \mathrm{C}$ for 5 hours. Samples were drawn at the start and after incubation. Samples were centrifuged and supernatants were analyzed for estimation of $\mathrm{As}(\mathrm{V})$ oxidation/reduction as reported by Cummings et al. [18] with slight modifications. Standard curve was created using known concentrations of $\mathrm{As}(\mathrm{V})$ ranging from zero to $1000 \mathrm{mM} \mathrm{As}(\mathrm{V}) .100 \mu \mathrm{L}$ of sample was mixed with $100 \mu \mathrm{L}$ of $24 \mathrm{mM} \mathrm{HCl}$ followed by immediate vortexing. $100 \mu \mathrm{L}$ of the acidified sample was mixed with $900 \mu \mathrm{L}$ of the coloring reagent followed by immediate vortexing. The samples were incubated at $78^{\circ} \mathrm{C}$ in a water bath for 20 minutes and kept on ice for 5 minutes. Samples were quantified at $865 \mathrm{~nm}$ using spectrophotometer (CECIL CE 7200).

2.5. Determination of Cross Metal Resistance. Selected isolates were tested for resistance against other metals. Media containing $1.0 \mathrm{mM} \mathrm{Co}\left(\mathrm{NO}_{3}\right)_{2} \cdot 6 \mathrm{H}_{2} \mathrm{O}, \mathrm{ZnSO}_{4} \cdot 7 \mathrm{H}_{2} \mathrm{O}, \mathrm{NiCl}_{2} \cdot 6 \mathrm{H}_{2} \mathrm{O}$, $\mathrm{CdCl}_{2} \cdot 5 \mathrm{H}_{2} \mathrm{O}, \mathrm{K}_{2} \mathrm{CrO}_{4}$, or $\mathrm{CuSO}_{4} \cdot 5 \mathrm{H}_{2} \mathrm{O}$ each were prepared. The media flasks were inoculated with overnight broth cultures and incubated at $37^{\circ} \mathrm{C}$ for 72 hours. After completion of incubation, absence or presence of growth was recorded.

2.6. 16S rRNA Gene Sequencing and Phylogenetic Analysis. $16 \mathrm{~S}$ rRNA gene of selected PNSB was sequenced from 
TABLE 1: Characteristics of As-resistant PNSB isolated in this study.

\begin{tabular}{|c|c|c|c|c|c|c|c|c|c|}
\hline Strain & Gram reaction & $\begin{array}{c}\text { Spore } \\
\text { staining }\end{array}$ & Catalase & Oxidase & $\begin{array}{c}\text { Auxin } \\
\text { production }\end{array}$ & $\begin{array}{c}\mathrm{HCN} \\
\text { production }\end{array}$ & Phosphate & $\begin{array}{c}\text { As }(\mathrm{V})- \\
\text { reduction }\end{array}$ & $\begin{array}{c}\text { As(III)- } \\
\text { oxidation }\end{array}$ \\
\hline CS1 & Gram-negative & - & Positive & Positive & + & +++ & - & +++ & - \\
\hline CS2 & Gram-negative & - & Positive & Positive & + & ++ & - & +++ & - \\
\hline CS4 & Gram-negative & - & Positive & Positive & + & - & - & +++ & - \\
\hline SS5 & Gram-negative & - & Positive & Positive & + & +++ & - & - & +++ \\
\hline SS6 & Gram-negative & - & Positive & Positive & + & - & + & +++ & - \\
\hline SS7 & Gram negative & - & Positive & Positive & + & ++ & - & - & + \\
\hline SS8 & Gram-negative & - & Positive & Positive & + & - & - & + & - \\
\hline SS9 & Gram-negative & - & Positive & Positive & + & - & - & - & + \\
\hline
\end{tabular}

Macrogen (Korea) using primers 518F (CCAGCAGCCGCGGTAATACG) and 800R (TACCAGGGTATCTAATCC). Base call quality was checked though FinchTV. Sequences were classified using NCBI BLAST (https://blast.ncbi.nlm.nih.gov/Blast.cgi?PAGE_TYPE=BlastSearch) and nearest homologues were downloaded. Multiple sequence alignment was done in ClustalW. NeighbourJoining (NJ) phylogenetic tree [19] was made in MEGA 5.0 [20] with 100 bootstrap replicates [21] as an estimate of branch support.

\subsection{Plant Growth Promoting Attributes of PNSB}

2.7.1. Auxin Production. LB-broth supplemented with $500 \mathrm{mg} \mathrm{mL}^{-1}$ tryptophan was prepared and inoculated with overnight PNSB cultures followed by 7 days of incubation at $37^{\circ} \mathrm{C}$ on $150 \mathrm{rpm}$ agitation. Following incubation, cultures were centrifuged and $100 \mu \mathrm{L}$ supernatant was mixed with $200 \mu \mathrm{L}$ Salkowski's reagent $\left(1.0 \mathrm{~mL} 0.05 \mathrm{M} \mathrm{FeCl}_{3}, 50 \mathrm{~mL} 35 \%\right.$ $\mathrm{HClO}_{4}$ ) [22] in microtiter plate followed by incubation in dark for 30 minutes. Appearance of pinkish color indicated auxin production. Absorbance was measured at $535 \mathrm{~nm}$ using Epoch BioTek plate reader.

2.7.2. Phosphate Solubilization. PNSB were streaked on Pikovskaya [23] media followed by incubation at $28^{\circ} \mathrm{C}$ for 7 days. Following incubation, plates were observed for the presence or absence of clear zones around PNSB colonies, an indication of phosphate solubilization.

2.7.3. Hydrogen Cyanide (HCN) Production. PNSB were swabbed on nutrient agar supplemented with glycine $\left(4.4 \mathrm{gm} \mathrm{L}^{-1}\right)$ and a filter paper soaked in $2.0 \% \mathrm{Na}_{2} \mathrm{CO}_{3}$ solution (in $0.5 \%$ picric acid) was placed on the top of the agar surface $[24,25]$. After incubation at $28^{\circ} \mathrm{C}$ for 4 days, development of orange to red color of the filter paper indicated the positive result for HCN production.

2.8. Plant-Microbe Interaction Experiments. PNSB were cultured in Pfennig broth media as described earlier. Cells were harvested and resuspended in autoclave water to achieve $0.5_{600 \mathrm{~nm}}$ optical density. Vigna mungo seeds, purchased from Punjab Seed Corporation, were surface-sterilized with $0.1 \%$
$\mathrm{HgCl}_{2}$ for 2.0 minutes with continuous shaking followed by washing with distilled water, 3-4 times. Seeds were incubated in separate as well as in mixed PNSB suspensions (consortium) for 15-20 minutes at room temperature. Following incubation, seeds were sown in $16 \mathrm{~cm}$ wide and $13.5 \mathrm{~cm}$ deep pots each containing equal amount of sieved soil. Eight seeds were sown per pot and after germination plants were thinned to five plants per pot. Pots were divided into 4 sets: (a) pots containing uninoculated seeds, (b) pots containing inoculated seeds, (c) pots containing uninoculated seeds and As $[1.0 \mathrm{mM} \mathrm{As}(\mathrm{V})$ and $0.1 \mathrm{mM} \mathrm{As}(\mathrm{III})]$, and (d) the pots containing inoculated seeds as well as As [1.0 mM As(V) and $0.1 \mathrm{mM} \mathrm{As}(\mathrm{III})]$. Each set contained 10 pots. The pots were placed in 12-hour photoperiod at $25 \pm 2{ }^{\circ} \mathrm{C}$ for two weeks. Watering was done regularly.

2.9. Statistical Analysis. Results were analyzed for statistical significance using analysis of variance (ANOVA), followed by post hoc analysis using two-tailed $t$-tests $(p=0.05)$ in order to compare different treatments with each other. The threshold of significance was also adjusted using Bonferroni correction. All the biostatistical analysis was done using Microsoft Excel 2013 data analysis toolkit.

\section{Results}

3.1. Isolation and Identification of As-Resistant PNSB. Purplish maroon colored bloom was achieved in the enrichment Schott bottles after incubation of 10 days at $28^{\circ} \mathrm{C}$ in incandescent light. Media containing sodium acetate and sodium lactate did not show any growth. Malic acid containing media

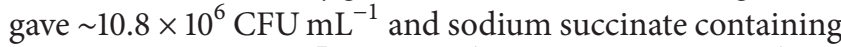
media gave $\sim 7 \times 10^{7} \mathrm{CFU} \mathrm{mL}^{-1}$, whereas $\mathrm{CFU} \mathrm{mL}^{-1}$ on sodium citrate containing media was $2 \times 10^{7}$ (Table 1 ). All the isolated PNSB were catalase and oxidase positive. All isolates were Gram-negative and nonspore former (Table 1).

$16 \mathrm{~S}$ rRNA sequence analysis of the PNSB showed that isolate CS2 showed maximum homology to Rhodopseudomonas palustris (99\%), whereas isolate SS5 showed maximum homology to Rhodopseudomonas faecalis (99\%), when aligned through nucleotide BLAST tool of NCBI. The results were confirmed by making NJ-phylogenetic tree. Isolate CS2 grouped with $R$. palustris, whereas isolate SS5 grouped 


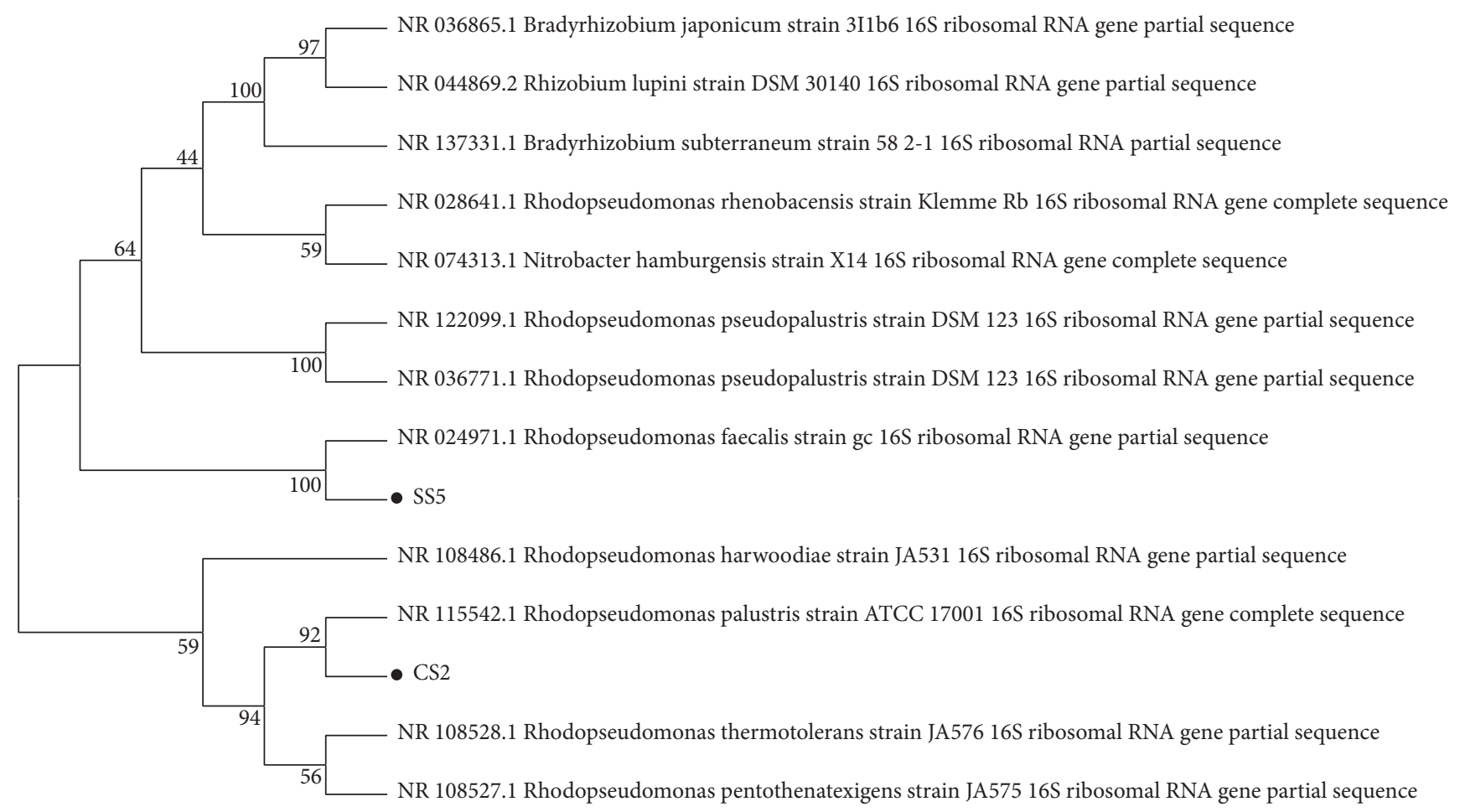

FIGURE 1: NJ-phylogenetic tree of PNSB isolates CS2 and SS5 along with their closest homologues from NCBI nucleotide BLAST results. Sequences were aligned with ClustalW and tree was made in MEGA 5 using 100 bootstrap replicates. Isolate CS2 grouped with Rhodopseudomonas palustris and SS5 grouped with Rhodopseudomonas faecalis.

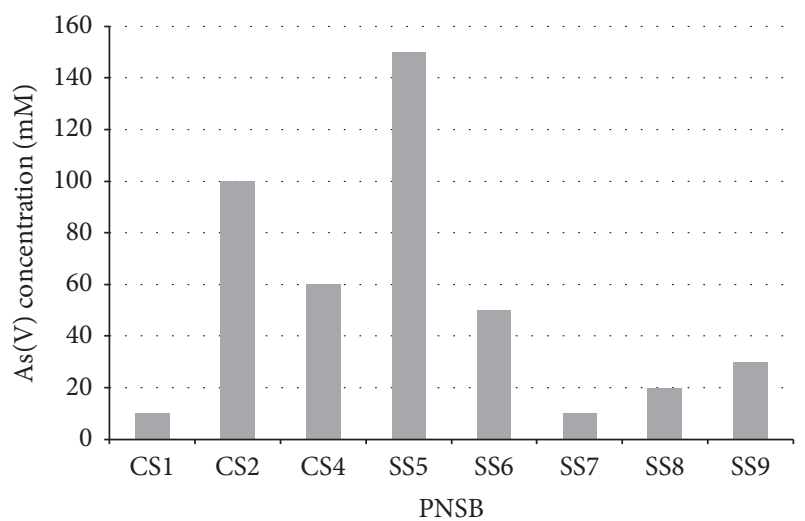

Figure 2: Minimum inhibitory concentration of $\mathrm{As}(\mathrm{V})$ against PNSB. Highest concentration of As $(V)$ was resisted by $R$. faecalis SS5 and $R$. palustris CS2, up to 150 and $100 \mathrm{mM}$, respectively.

with $R$. faecalis (Figure 1). The sequences were submitted in NCBI GenBank under the accession numbers KY098792 and KY098793 for $R$. palustris CS2 and R. faecalis SS5, respectively.

3.2. Heavy Metal Resistance. Maximum As(V) resistance was shown by $R$. faecalis SS5, up to $150 \mathrm{mM}$, whereas $R$. palustris $\mathrm{CS} 2$ resisted up to $100 \mathrm{mM}$ As(V) (Figure 2). All the isolates were resistant to $1.0 \mathrm{mM} \mathrm{Cr}, \mathrm{Ni}$, and $\mathrm{Zn}$, while they were sensitive to the $\mathrm{Cu}, \mathrm{Cd}$, and $\mathrm{Co}$.
3.3. Estimation of As-Oxidation/Reduction. $\mathrm{KMNO}_{4}$ was used as reagent which changes its color to yellow in presence of As(III) but retains its color in the presence of As(V). $R$. palustris CS2 was found to be As $(\mathrm{V})$ reducers, while $R$. faecalis SS5 was found to be As(III)-oxidizer (Table 1).

Isolates $R$. palustris CS2 showed highest As(V) reduction potential and reduced $62.9 \%(6.29 \pm 0.24 \mathrm{mM}) \mathrm{As}(\mathrm{V})$ in 5 hours of incubation. Isolates CS4 and SS6 reduced $48 \%$ $(4.8 \pm 0.4 \mathrm{mM}) \mathrm{As}(\mathrm{V})$, whereas isolate SS6 reduced $42 \%(4.2 \pm$ $0.31 \mathrm{mM})$ As(V). Maximum As(III) oxidation was exhibited by $R$. faecalis SS5 and oxidized 96\% (4.8 $\pm 0.32 \mathrm{mM})$ As(III) in 5 hours of incubation (Figure 3 ).

3.4. Plant Growth Promoting Activities of PNSB. Isolate $R$. faecalis SS5 was strongly positive for the HCN production, while $R$. palustris CS2 was weakly positive as indicated by the intensity of the orange color developed on the filter paper (Table 1). All the isolates were positive for auxin production as well and maximum auxin production was exhibited by $R$. palustris CS2 (77.18 $\left.\pm 3.7 \mu \mathrm{g} \mathrm{mL}^{-1}\right)$ and $R$. faecalis SS5 (76.67 \pm $2.8 \mu \mathrm{g} \mathrm{mL}^{-1}$ ) (Figure 4). All the isolates were negative for phosphate solubilization (Table 1).

3.5. Effects of PNSB on Plant Growth. Different sets of pots showed different germination rates according to the conditions provided. Germination rate was affected in the presence of As (data not shown).

Control plants were exposed neither to As nor to PNSB. Average shoot length was $24.0 \pm 0.9 \mathrm{~cm}$, while average root 


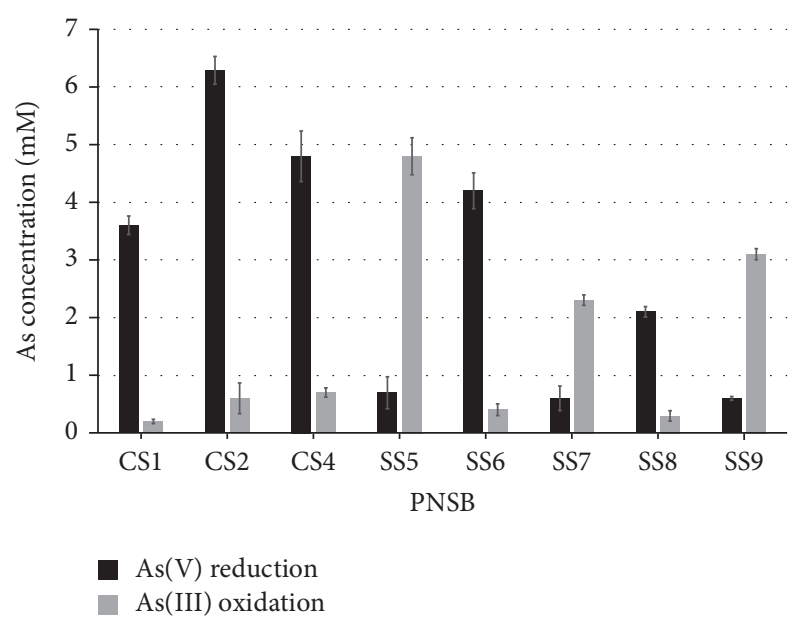

FIgURE 3: As-oxidation/reduction by PNSB. Bacterial cell suspensions were incubated for 5 hours in normal saline containing either $10 \mathrm{mM}$ As(V) or $5 \mathrm{mM}$ As(III). Highest As(V) reduction was shown by $R$. palustris CS2 up to $62.9 \%(6.29 \pm 0.24 \mathrm{mM})$, whereas highest As(III) oxidation was shown by $R$. faecalis SS5 up to $96 \%$ (4.8 \pm $0.32 \mathrm{mM})$.

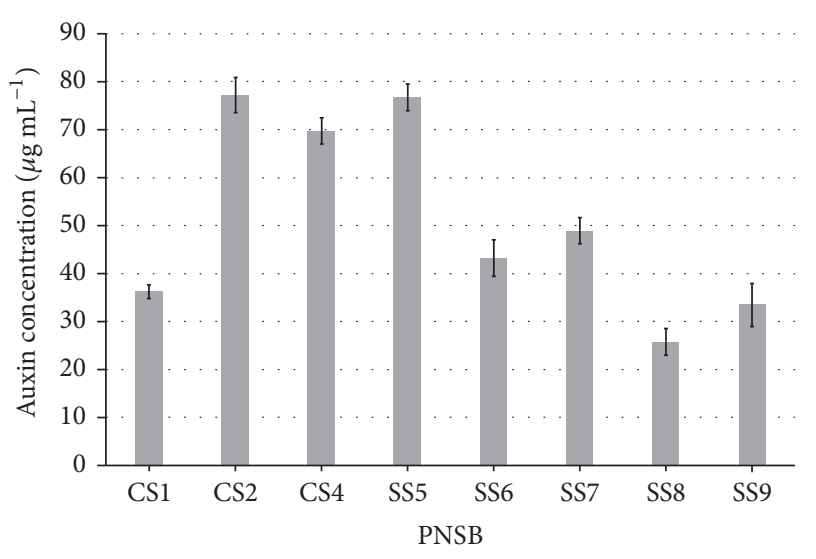

FIgUre 4: Auxin production by As-resistant PNSB. $R$. palustris CS2 and $R$. faecalis SS5 produced highest auxin concentrations up to $77.18 \pm 3.7$ and $76.67 \pm 2.8 \mu \mathrm{g} \mathrm{mL}^{-1}$.

length was $5.8 \pm 0.5 \mathrm{~cm}$. Increase in shoot and root length was observed in the presence of PNSB. $R$. palustris CS2 treated plants showed $17 \%(28.1 \pm 0.87 \mathrm{~cm})$ increase in shoot length and $21.7 \%(7.07 \pm 0.42 \mathrm{~cm})$ increase in root length as compared to the control plants. $R$. faecalis SS5 treated plants showed $12.8 \%(27.09 \pm 0.81 \mathrm{~cm})$ increase in shoot length and $18.8 \%(6.9 \pm 0.34 \mathrm{~cm})$ increase in root length as compared to the control plants. Shoot length of the plants treated with mixed isolates ( $R$. palustris CS2 and R. faecalis SS5) increased up to $15.4 \%(27.7 \pm 0.67 \mathrm{~cm})$, whereas root length increased up to $24.2 \%(7.2 \pm 0.52 \mathrm{~cm})$ as compared to the control plants (Figure 5).

Shoot and root lengths of plants exposed to As decreased up to $30.7 \%(16.6 \pm 0.58 \mathrm{~cm})$ and $29.7 \%(4.08 \pm 0.76 \mathrm{~cm})$, respectively. Plants exposed to both $\mathrm{As}(\mathrm{V})$ and PNSB showed increased root and shoot lengths. Shoot length of plants treated with As and R. palustris CS2 increased up to $26.3 \%$ $(21.0 \pm 1.1 \mathrm{~cm})$, while root length increased up to $31.3 \%$ (5.3 \pm $0.4 \mathrm{~cm}$ ) as compared to the control plants (plants exposed to As). R. faecalis SS5 inoculated plants showed 25\% (20.7 \pm $1.4 \mathrm{~cm})$ increase in shoot length and $33.3 \%(5.4 \pm 0.65 \mathrm{~cm})$ increase in root length in presence of As as compared to control plants. Shoot and root lengths of plants treated with mixed isolates in presence of As increased up to $33 \%(22.1 \pm$ $0.7 \mathrm{~cm})$ and $36.7 \%(5.5 \pm 0.4 \mathrm{~cm})$, respectively (Figure 6).

ANOVA of all the plant sets was significant, and Bonferroni corrected posttest $t$-test indicated that the length of plants exposed to As was significantly lower and the length of plants exposed to PNSB was significantly higher, compared to control plants (not exposed to As) ( $p \leq 0.05)$. The statistical analysis also confirmed that the length of plants exposed to both As and PNSB was significantly higher as compared to plants exposed to As only $(p \leq 0.05)$.

Wet and dry weight of plants exposed to neither As nor PNSB was $1.4 \pm 0.1 \mathrm{gm}$ and $0.2 \pm 0.05 \mathrm{gm}$, respectively. $R$. palustris CS2 inoculated plants had $1.7 \pm 0.1 \mathrm{gm}$ wet weight, while the dry weight was $0.3 \pm 0.03 \mathrm{gm}$. Wet weight of $R$. faecalis SS5 treated plants was $1.6 \pm 0.2 \mathrm{gm}$, whereas the dry weight was $0.2 \pm 0.04 \mathrm{gm}$.

Wet and dry weight of plants exposed to As was $0.9 \pm$ $0.08 \mathrm{gm}$ and $0.09 \pm 0.01 \mathrm{gm}$, respectively. $R$. palustris CS2 treated plants had $1.25 \pm 0.8 \mathrm{gm}$ wet weight in the presence of As, while the dry weight was $0.14 \pm 0.03 \mathrm{gm}$. Wet weight of $R$. faecalis SS5 treated plants, in presence of As, was $1.1 \pm 0.3 \mathrm{gm}$, whereas the dry weight was $0.12 \pm 0.07 \mathrm{gm}$.

\section{Discussion}

Resistance against $\mathrm{As}(\mathrm{V})$ and plant growth promoting activities, such as auxin and HCN production, were the main parameters used for the screening and selection of PNSB. PNSB are known to utilize different carbon sources including those of TCA cycle, as well as different fatty acids and even fix $\mathrm{CO}_{2}$ for their growth $[26,27]$. In the present study, As-resistant PNSB isolates were able to utilize malic acid, sodium succinate, or sodium citrate. The isolates showing best results were identified as $R$. palustris CS2 and R. faecalis SS5 by aligning their $16 \mathrm{~S}$ rRNA gene sequences with the NCBI nucleotide database using BLAST tool. Rhodopseudomonas and many other PNSB belong to $\alpha$-proteobacteria; however, some PNSB are also found in $\beta$-proteobacteria [28]. Both qualitative and quantitative assays of As-oxidation/reduction showed that $R$. palustris CS2 had ability to reduce $\mathrm{As}(\mathrm{V})$ into As(III), whereas $R$. faecalis SS5 had the potential to oxidize As(III) to As(V). Genetic determinants of As-resistance and detoxification are found in the form of an operon called ars operon; thus the ability to resist and detoxify As is mostly linked together [29]. Bacteria are known to oxidize as well as reduce As, and even some bacteria are reported to perform both functions [30, 31]. Thus PNSB have important roles to play in the biogeochemical cycling of As as well.

Bacteria are also known to produce different phytohormones that enhance plants' growth [32]. IAA, a type of auxin, exhibits one of the greatest plant growth promoting activity [33]. Both isolates $R$. palustris CS2 and $R$. faecalis 


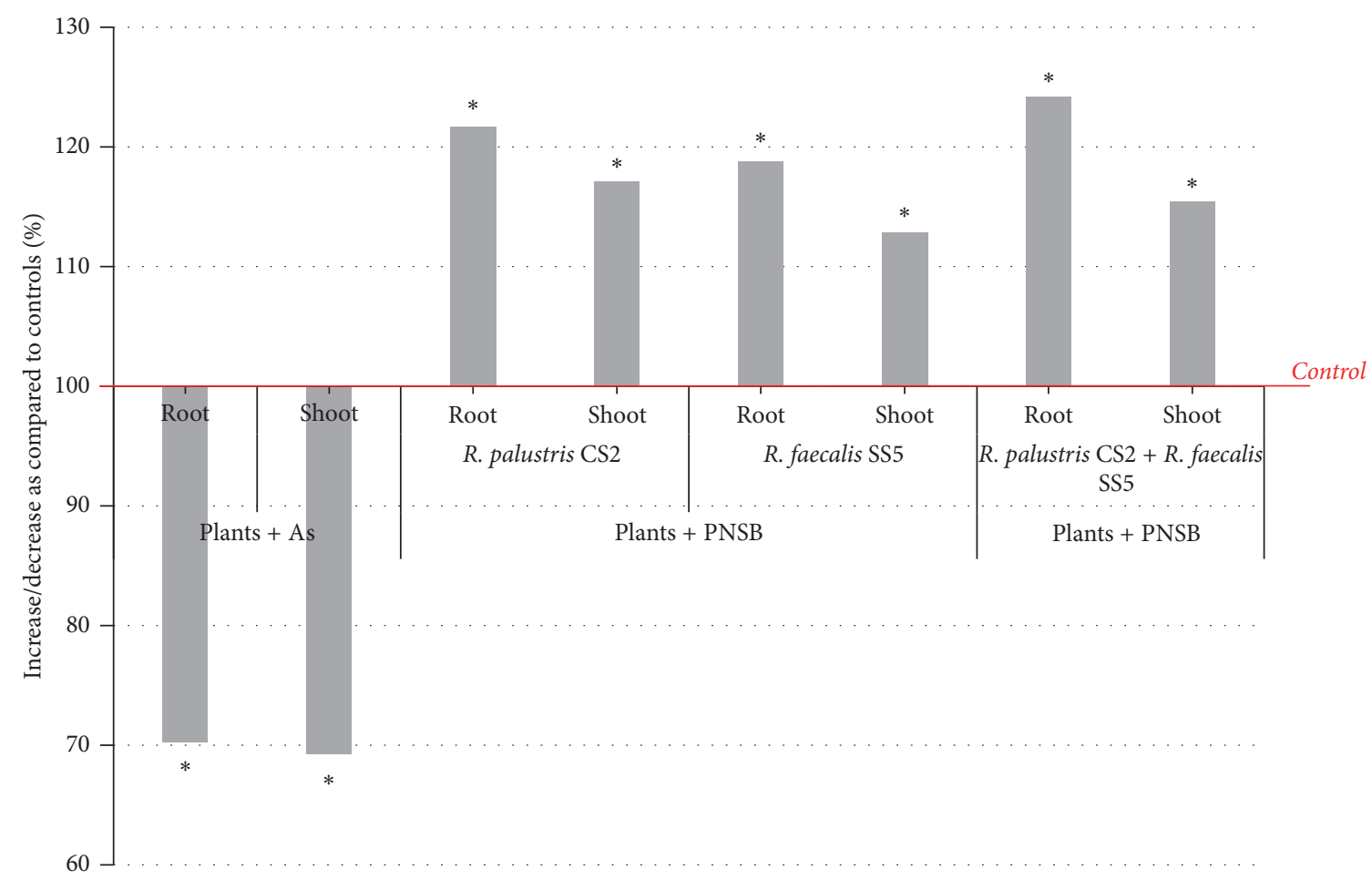

Figure 5: Effects of As and PNSB on Vigna mungo growth as compared to the control plants (control = 100\%, plants exposed neither to As nor PNSB). In presence of As, shoot and root lengths decreased up to $30.7 \%$ and $29.7 \%$, respectively, as compared to the control plants. In presence of $R$. palustris CS2, shoot and root lengths increased up to 17 and 21.7\%, whereas in presence of $R$. faecalis SS5 shoot and root lengths increased up to 12.8 and $18.8 \%$, respectively. In presence of both $R$. palustris CS2 and $R$. faecalis SS5, shoot length and root length increased up to 15.4 and $24.2 \%$, respectively. ${ }^{*}$ Significantly different from control, $p<0.05$.

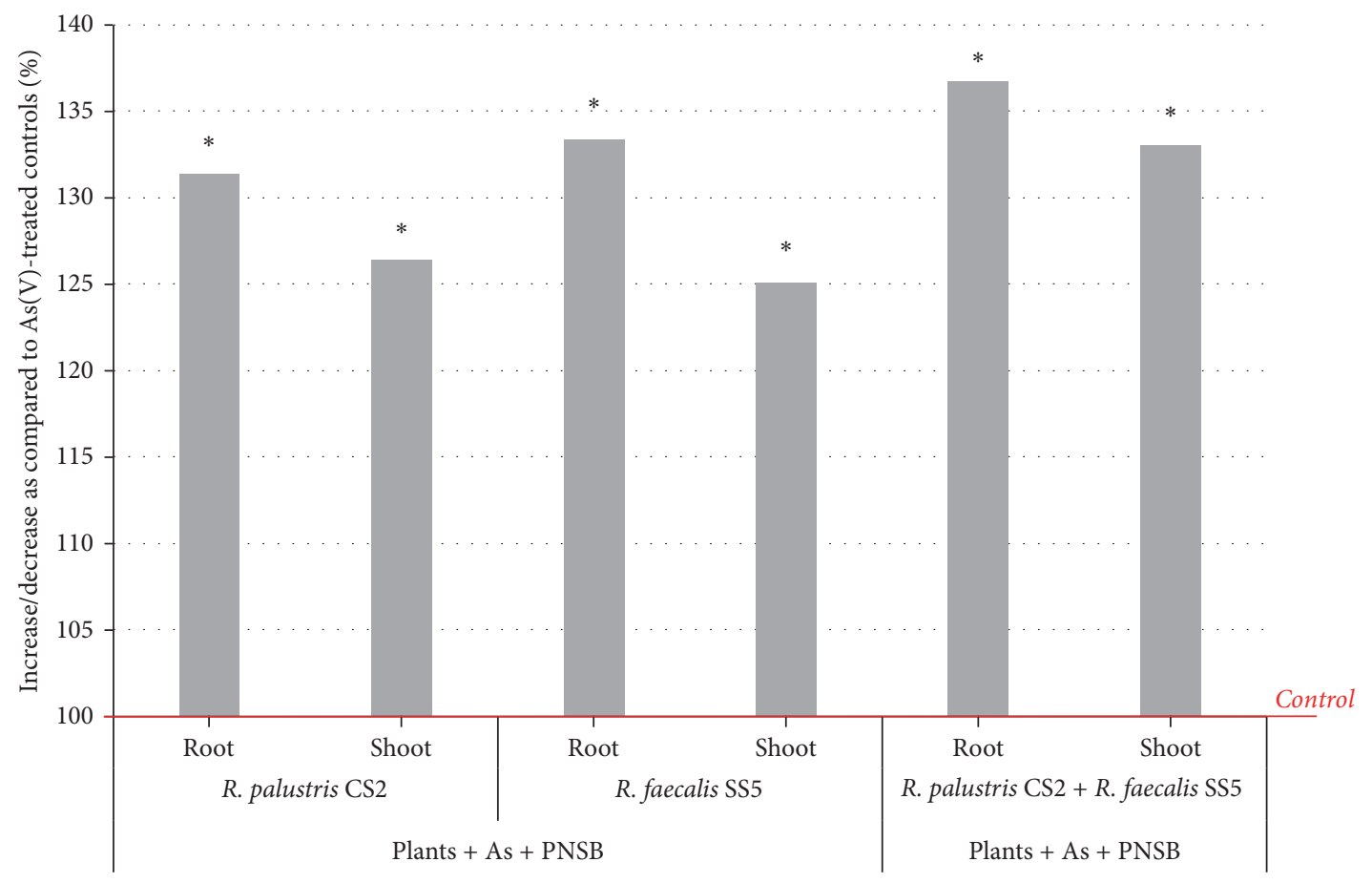

FIGURE 6: Effects of As-resistant PNSB on Vigna mungo growth in presence of As compared to the control plants (control = 100\%, plants exposed to As). R. palustris CS2 treated plants showed 26.3 and $31.3 \%$ increase in shoot and root length, respectively, whereas $R$. faecalis SS5 treated plants showed 25 and $33.3 \%$ increase in shoot and root length, respectively, as compared to the control plants. Shoot and root lengths of plant treated with both $R$. palustris CS2 and $R$. faecalis SS5 increased up to 33\% and 36.7\%, respectively. * Significantly different from control, $p<0.05$. 
SS5 showed highest level of auxin production. Hydrogen cyanide is another secondary metabolite important for plant growth. $R$. palustris CS2 and R. faecalis SS5 were also found to produce hydrogen cyanide. Plant growth promoting ability of these isolates was checked with $V$. mungo due to its fast growth rate. Both $R$. palustris CS2 and $R$. faecalis SS5 were able to enhance the growth of plants both in presence and in absence of As. The increase in the growth of plants due to PNSB in presence of As could be due to the reason that PNSB were able to oxidize/reduce As present in the soil, thus decreasing the bioavailability of As to the plants. Moreover, as these PNSB were also capable of producing phytohormones, this added extra benefit for the growth of the plants. Combined effect of $R$. palustris CS2 and $R$. faecalis SS5 was more pronounced for root enhancement. This could be due to the fact that mixed bacteria were able to oxidize As(III) as well as reduce As(V), keeping a redox cycle and thus further decreasing the bioavailability of As to the plants. Table S1 (see Supplementary Material available online at https://doi.org/10.1155/2017/6250327) shows some of the studies that report As-oxidation/reduction or plant growth promotion by PNSB. As the table indicates, many Rhodopseudomonas and Rhodobacter species are known to support plant growth by producing phytohormones. Nookongbut et al. [14] reported As-resistance and detoxification by different strains of $R$. palustris. Wong et al. [34] reported IAA production as well as plant growth enhancement by $R$. palustris. However, literature reporting both As-detoxification and plant growth promotion by same PNSB strains is scarce. The present study reports this important aspect of PNSB strains which can be utilized to enhance plant growth in As-contaminated areas.

\section{Conclusions}

Metabolically diverse bacteria such as PNSB with ability to not only detoxify As but also support plant growth could be useful both in bioremediation of As-contaminated lands and in supporting plant growth in such contaminated sites.

\section{Competing Interests}

The authors have no conflict of interests in these results.

\section{Authors' Contributions}

Kanza Batool performed all the experiments and wrote the manuscript. Fatima tuz Zahra performed As-analysis. Yasir Rehman supervised the study and edited the manuscript.

\section{Acknowledgments}

University of the Punjab, Lahore, Pakistan, is acknowledged for providing funds to conduct this research.

\section{References}

[1] WHO, Guidelines for Drinking-Water Quality: Incorporating 1st and 2nd Addenda, Volume 1: Recommendations, World Health Organization, Geneva, Switzerland, 2008.
[2] R. S. Oremland and J. F. Stolz, “The ecology of arsenic," Science, vol. 300, no. 5621, pp. 939-944, 2003.

[3] National Academy of Sciences, Medical and Biological Effects of Environmental Pollutants-Arsenic, National Academy of Sciences, Washington, DC, USA, 1977.

[4] C. K. Jain and I. Ali, "Arsenic: occurrence, toxicity and speciation techniques," Water Research, vol. 34, no. 17, pp. 4304-4312, 2000.

[5] T. Řezanka and K. Sigler, "Biologically active compounds of semi-metals," Phytochemistry, vol. 69, no. 3, pp. 585-606, 2008.

[6] M. Patra, N. Bhowmik, B. Bandopadhyay, and A. Sharma, "Comparison of mercury, lead and arsenic with respect to genotoxic effects on plant systems and the development of genetic tolerance," Environmental and Experimental Botany, vol. 52, no. 3, pp. 199-223, 2004.

[7] C.-X. Li, S.-L. Feng, Y. Shao, L.-N. Jiang, X.-Y. Lu, and X.-L. Hou, "Effects of arsenic on seed germination and physiological activities of wheat seedlings," Journal of Environmental Sciences, vol. 19, no. 6, pp. 725-732, 2007.

[8] J. F. Stolz, P. Basu, J. M. Santini, and R. S. Oremland, "Arsenic and selenium in microbial metabolism," Annual Review of Microbiology, vol. 60, pp. 107-130, 2006.

[9] M. K. Kim, K.-M. Choi, C.-R. Yin et al., "Odorous swine wastewater treatment by purple non-sulfur bacteria, Rhodopseudomonas palustris, isolated from eutrophicated ponds," Biotechnology Letters, vol. 26, no. 10, pp. 819-822, 2004.

[10] K. Takeno, Y. Yamaoka, and K. Sasaki, “Treatment of oil-containing sewage wastewater using immobilized photosynthetic bacteria," World Journal of Microbiology and Biotechnology, vol. 21, no. 8-9, pp. 1385-1391, 2005.

[11] H. Gamal-Eldin and K. Elbanna, "Field evidence for the potential of Rhodobacter capsulatus as biofertilizer for flooded rice," Current Microbiology, vol. 62, no. 2, pp. 391-395, 2011.

[12] R. H. Koh and H.-G. Song, "Effects of application of Rhodopseudomonas sp. on seed germination and growth of tomato under axenic conditions," Journal of Microbiology and Biotechnology, vol. 17, no. 11, pp. 1805-1810, 2007.

[13] G. Holguin, P. Vazquez, and Y. Bashan, "The role of sediment microorganisms in the productivity, conservation, and rehabilitation of mangrove ecosystems: an overview," Biology and Fertility of Soils, vol. 33, no. 4, pp. 265-278, 2001.

[14] P. Nookongbut, D. Kantachote, and M. Megharaj, "Arsenic contamination in areas surrounding mines and selection of potential As-resistant purple nonsulfur bacteria for use in bioremediation based on their detoxification mechanisms," Annals of Microbiology, vol. 66, no. 4, pp. 1419-1429, 2016.

[15] H. Biebl and N. Pfennig, "Isolation of members of the family Rhodospirillaceae," in The Prokaryotes: A Handbook on Habitats, Isolation, and Identification of Bacteria, M. P. Starr, H. Stolp, H. G. Trüper, A. Balows, and H. G. Schlegel, Eds., pp. 267-273, Springer, Berlin, Germany, 1981.

[16] C. Brunner, M. Wolf, and R. Bachofen, "Enrichment of bitumen-degrading microorganisms," FEMS Microbiology Letters, vol. 43, no. 3, pp. 337-344, 1987.

[17] T. M. Salmassi, K. Venkateswaren, M. Satomi, K. H. Nealson, D. K. Newman, and J. G. Hering, "Oxidation of arsenite by Agrobacterium albertimagni, AOL15, sp. nov., isolated from Hot Creek, California," Geomicrobiology Journal, vol. 19, no. 1, pp. 53-66, 2002. 
[18] D. E. Cummings, F. Caccavo Jr., S. Fendorf, and R. F. Rosenzweig, "Arsenic mobilization by the dissimilatory $\mathrm{Fe}(\mathrm{III})$ reducing bacterium Shewanella alga BrY," Environmental Science \& Technology, vol. 33, no. 5, pp. 723-729, 1999.

[19] N. Saitou and M. Nei, "The neighbor-joining method: a new method for reconstructing phylogenetic trees," Molecular Biology and Evolution, vol. 4, no. 4, pp. 406-425, 1987.

[20] K. Tamura, D. Peterson, N. Peterson, G. Stecher, M. Nei, and S. Kumar, "MEGA5: molecular evolutionary genetics analysis using maximum likelihood, evolutionary distance, and maximum parsimony methods," Molecular Biology and Evolution, vol. 28, no. 10, pp. 2731-2739, 2011.

[21] J. Felsenstein, "Confidence limits on phylogenies: an approach using the Bootstrap," Evolution, vol. 39, no. 4, pp. 783-791, 1985.

[22] S. A. Gordon and R. P. Weber, "Colorimetric estimation of indoleacetic acid," Plant Physiology, vol. 26, no. 1, pp. 192-195, 1951.

[23] R. E. Pikovskaya, "Mobilization of phosphorus in soil in connection with vital activity of some microbial species," Mikrobiologiya, vol. 17, pp. 362-370, 1948.

[24] A. P. G. C. Marques, C. Pires, H. Moreira, A. O. S. S. Rangel, and P. M. L. Castro, "Assessment of the plant growth promotion abilities of six bacterial isolates using Zea mays as indicator plant," Soil Biology and Biochemistry, vol. 42, no. 8, pp. 12291235, 2010.

[25] H. Lorck, "Production of hydrocyanic acid by bacteria," Physiologia Plantarum, vol. 1, no. 2, pp. 142-146, 1948.

[26] F. R. Tabita, "The biochemistry and metabolic regulation of carbon metabolism and $\mathrm{CO}_{2}$ fixation in purple bacteria," in Anoxygenic Photosynthetic Bacteria, R. E. Blankenship, M. T. Madigan, and C. E. Bauer, Eds., pp. 885-914, Springer, Dordrecht, the Netherlands, 1995.

[27] Y.-K. Oh, E.-H. Seol, M.-S. Kim, and S. Park, "Photoproduction of hydrogen from acetate by a chemoheterotrophic bacterium Rhodopseudomonas palustris P4," International Journal of Hydrogen Energy, vol. 29, no. 11, pp. 1115-1121, 2004.

[28] J. A. Lake, J. Larsen, B. Sarna et al., "Rings reconcile genotypic and phenotypic evolution within the Proteobacteria," Genome Biology and Evolution, vol. 7, no. 12, pp. 3434-3442, 2015.

[29] S. Silver and L. T. Phung, "Genes and enzymes involved in bacterial oxidation and reduction of inorganic arsenic," Applied and Environmental Microbiology, vol. 71, no. 2, pp. 599-608, 2005.

[30] H. Fan, C. Su, Y. Wang et al., "Sedimentary arsenite-oxidizing and arsenate-reducing bacteria associated with high arsenic groundwater from Shanyin, Northwestern China," Journal of Applied Microbiology, vol. 105, no. 2, pp. 529-539, 2008.

[31] M. Shafique, A. Jawaid, and Y. Rehman, "As(V) reduction, As(III) oxidation, and Cr(VI) reduction by multi-metal-resistant Bacillus subtilis, Bacillus safensis, and Bacillus cereus species isolated from wastewater treatment plant," Geomicrobiology Journal, pp. 1-8, 2016.

[32] F. Ahmad, I. Ahmad, and M. S. Khan, "Screening of free-living rhizospheric bacteria for their multiple plant growth promoting activities," Microbiological Research, vol. 163, no. 2, pp. 173-181, 2008.

[33] E. A. Tsavkelova, S. Y. Klimova, T. A. Cherdyntseva, and A. I. Netrusov, "Microbial producers of plant growth stimulators and their practical use: a review," Applied Biochemistry and Microbiology, vol. 42, no. 2, pp. 117-126, 2006.

[34] W.-T. Wong, C.-H. Tseng, S.-H. Hsu et al., "Promoting effects of a single Rhodopseudomonas palustris inoculant on plant growth by Brassica rapa chinensis under low fertilizer input," Microbes and Environments, vol. 29, no. 3, pp. 303-313, 2014. 

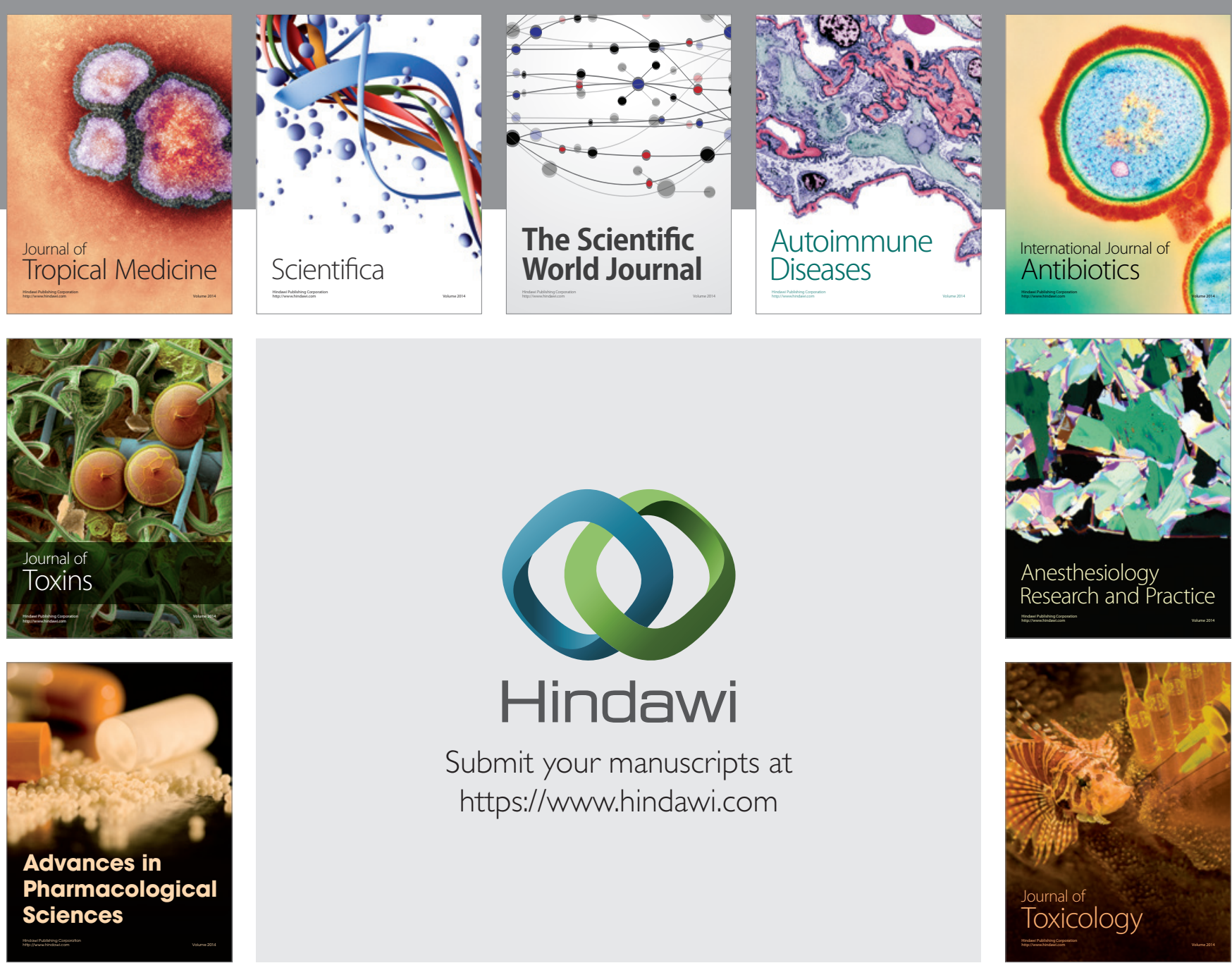

\section{Hindawi}

Submit your manuscripts at

https://www.hindawi.com
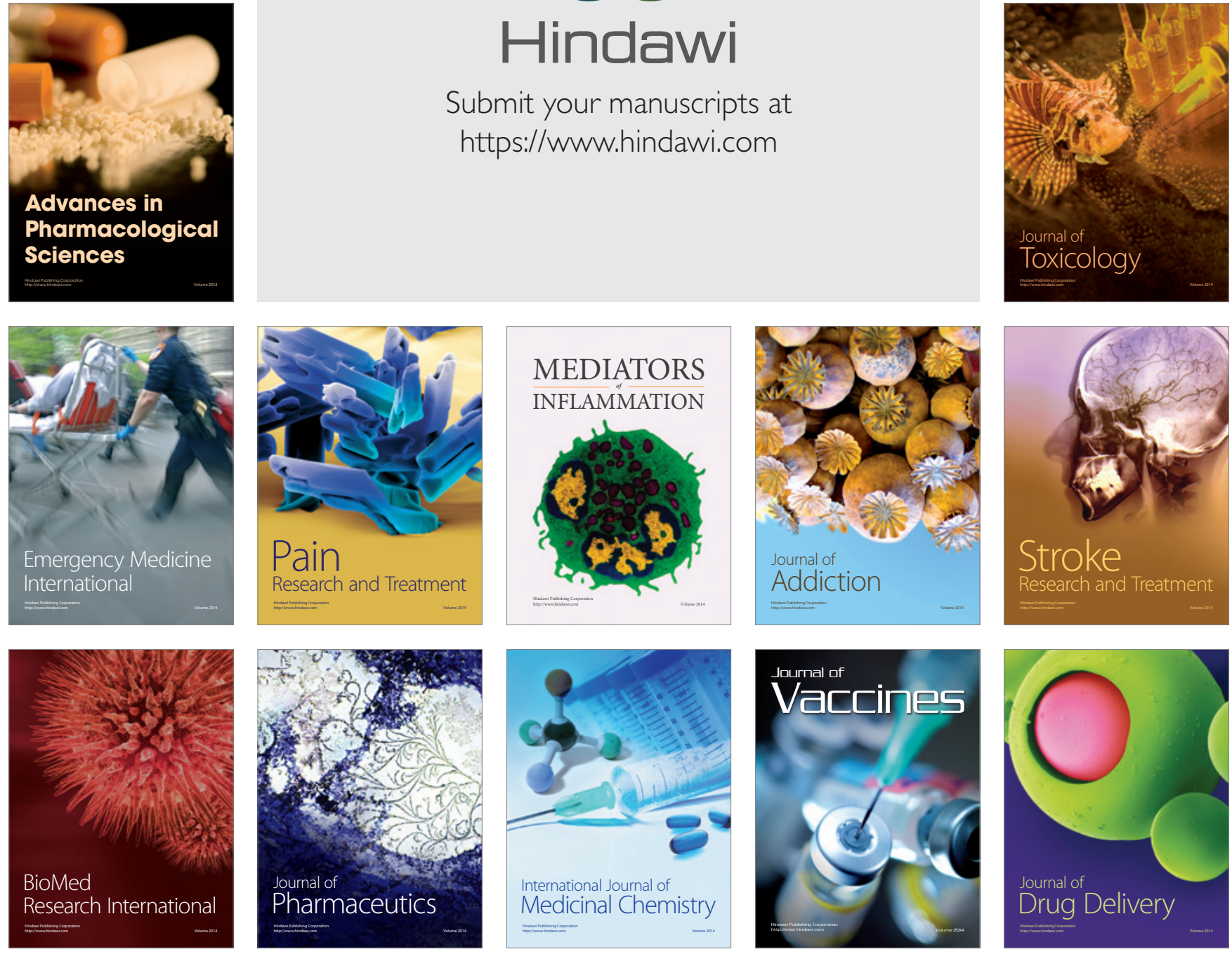